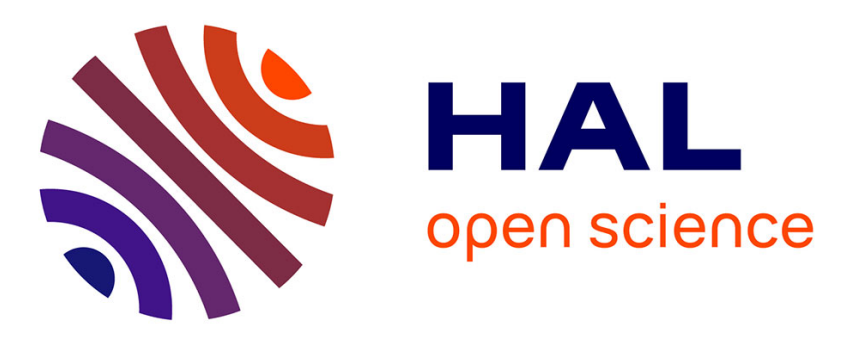

\title{
Changes in tolerance to herbicide toxicity throughout development stages of phototrophic biofilms
}

Armelle Paule, V. Roubeix, Béatrice Lauga, Robert Duran, François Delmas, Etienne Paul, Jean-Luc Rols

\section{- To cite this version:}

Armelle Paule, V. Roubeix, Béatrice Lauga, Robert Duran, François Delmas, et al.. Changes in tolerance to herbicide toxicity throughout development stages of phototrophic biofilms. Aquatic Toxicology, 2013, vol. 144-145, pp. 310-321. 10.1016/j.aquatox.2013.09.024 . hal-00913088

\section{HAL Id: hal-00913088 \\ https://hal.science/hal-00913088}

Submitted on 3 Dec 2013

HAL is a multi-disciplinary open access archive for the deposit and dissemination of scientific research documents, whether they are published or not. The documents may come from teaching and research institutions in France or abroad, or from public or private research centers.
L'archive ouverte pluridisciplinaire HAL, est destinée au dépôt et à la diffusion de documents scientifiques de niveau recherche, publiés ou non, émanant des établissements d'enseignement et de recherche français ou étrangers, des laboratoires publics ou privés. 


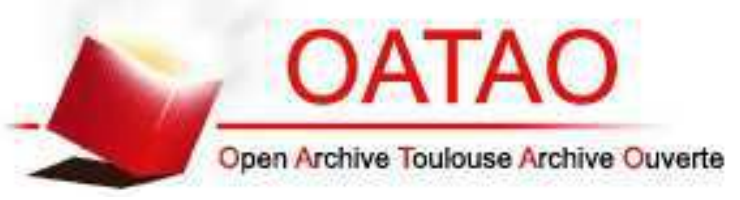

\section{Open Archive TOULOUSE Archive Ouverte (OATAO)}

OATAO is an open access repository that collects the work of Toulouse researchers and makes it freely available over the web where possible.

This is an author-deposited version published in : http://oatao.univ-toulouse.fr/ Eprints ID : 10241

To link to this article : doi:10.1016/j.aquatox.2013.09.024

URL : http://dx.doi.org/10.1016/j.aquatox.2013.09.024

To cite this version : Paule, Armelle and Roubeix, V. and Lauga, Béatrice and Duran, Robert and Delmas, François and Paul, Etienne and Rols, Jean-Luc Changes in tolerance to herbicide toxicity throughout development stages of phototrophic biofilms. (2013) Aquatic Toxicology, vol. 144-145 . pp. 310-321. ISSN 0166-445X

Any correspondance concerning this service should be sent to the repository administrator: staff-oatao@ listes-diff.inp-toulouse.fr 


\title{
Changes in tolerance to herbicide toxicity throughout development stages of phototrophic biofilms
}

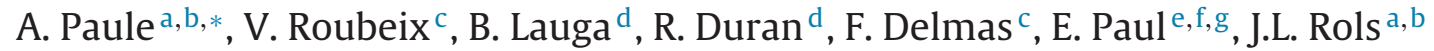 \\ a Université de Toulouse, UPS, INP, EcoLab (Laboratoire d'écologie fonctionnelle et environnement), 118 route de Narbonne, F-31062 Toulouse, France \\ b CNRS, ECoLab, F-31062 Toulouse, France \\ ' IRSTEA, UR REBX, Equipe de Recherche CARMA, 50 avenue de Verdun, F-33612 Cestas, France \\ d Equipe Environnement et Microbiologie, Institut Pluridisciplinaire de Recherche sur l'Environnement et les Matériaux - IPREM, UMR 5254 CNRS/UPPA, \\ IBEAS, Université de Pau et des Pays de l'Adour, BP 1155, F-64013 Pau, France \\ e Université de Toulouse, INSA, LISBP (Laboratoire Ingénierie des Systèmes Biologiques et des Procédés), 135 Avenue de Rangueil, F-31077 Toulouse, France \\ f INRA, UMR792 LISBP, F-31400 Toulouse, France \\ ${ }^{g}$ CNRS, UMR5504 LISBP, F-31400 Toulouse, France
}

Keywords:

Phototrophic biofilms

Diatoms

Bacterial communities

Ecological succession

Ecotoxicology

\begin{abstract}
A B S T R A C T
Ecotoxicological experiments have been performed in laboratory-scale microcosms to investigate the sensitivity of phototrophic biofilm communities to the alachlor herbicide, in relation to the stages of phototrophic biofilm maturation (age of the phototrophic biofilms) and physical structure (intact biofilm versus recolonization). The phototrophic biofilms were initially cultivated on artificial supports in a prototype rotating annular bioreactor (RAB) with Taylor-Couette type flow under constant operating conditions. Biofilms were collected after 1.6 and 4.4 weeks of culture providing biofilms with different maturation levels, and then exposed to nominal initial alachlor concentration of $10 \mu \mathrm{g} \mathrm{L}^{-1}$ in either intact or recolonized biofilms for 15 days in microcosms (mean time-weighted average concentration - TWAC of $\left.5.52 \pm 0.74 \mu \mathrm{g} \mathrm{L}^{-1}\right)$.

At the end of the exposure period, alachlor effects were monitored by a combination of biomass descriptors (ash-free dry mass - AFDM, chlorophyll a), structural molecular fingerprinting (T-RFLP), carbon utilization spectra (Biolog) and diatom species composition. We found significant effects that in terms of AFDM, alachlor inhibited growth of the intact phototrophic biofilms. No effect of alachlor was observed on diatom composition or functional and structural properties of the bacterial community regardless of whether they were intact or recolonized. The intact three-dimensional structure of the biofilm did not appear to confer protection from the effects of alachlor. Bacterial community structure and biomass level of 4.4 weeks - intact phototrophic biofilms were significantly influenced by the biofilm maturation processes rather than alachlor exposure. The diatom communities which were largely composed of mobile and colonizer life-form populations were not affected by alachlor.

This study showed that the effect of alachlor (at initial concentration of $10 \mu \mathrm{g} \mathrm{L}^{-1}$ or mean TWAC of $5.52 \pm 0.74 \mu \mathrm{g} \mathrm{L}^{-1}$ ) is mainly limited to biomass reduction without apparent changes in the ecological succession trajectories of bacterial and diatom communities and suggested that carbon utilization spectra of the biofilm are not damaged resulting. These results confirmed the importance of considering the influence of maturation processes or community age when investigating herbicide effects. This is particularly important with regard to the use of phototrophic biofilms as bio-indicators.
\end{abstract}

\section{Introduction}

Pesticides are one of the most important sources of pollution for continental aquatic environments (Kreuger, 1998). By mechanisms

\footnotetext{
* Corresponding author at: Université de Toulouse, UPS, INP, EcoLab (Laboratoire d'écologie fonctionnelle et environnement), 118 route de Narbonne, F-31062 Toulouse, France. Tel.: +3306 243819 04; fax: +3305 51556096.

E-mail address: arp778@mail.usask.ca (A.Paule).
}

including surface run-off, residual pesticides applied to agricultural lands migrate to surface and ground waters (e.g. Payraudeau et al., 2009). The intensive use of pesticides causes many disturbances in aquatic ecosystems (reviewed in DeLorenzo et al., 2001), the most important being the erosion of structural and/or functional biodiversity. In terms of ecotoxicology, the issue should not be limited to risk assessment on individual organisms but expanded to assessment at the ecosystem scale through the use of bioindicators to assess ecosystem health. In this context, for aquatic ecosystems, phototrophic biofilms, microbial aggregates composed 
of heterotrophic micro- and meio-organisms and phototrophic micro-organisms embedded in an exopolymeric matrix, provide a particularly relevant model, based on their complex microbial community structures, spatial and temporal dynamics and variety of ecosystem services functions. These aggregates are considered as a key compartment of aquatic environments due to their contribution to most of the primary production, food resource for aquatic grazers, mineralization and element recycling processes (Battin et al., 2003), absorption (Lawrence et al., 2001) and biodegradation of chemical contaminants (Vercraene-Eairmal et al., 2010). Phototrophic biofilms are susceptible to biological and biochemical perturbation by herbicides, resulting in damage to overall ecosystem functioning. Numerous studies (Pesce et al., 2011; Guasch et al., 2012), in field, microcosm or mesocosm, have detected the sensitivity of phototrophic biofilms to herbicides depending on: the chemical (Debenest et al., 2009), the structural or functional endpoint observed (Villeneuve et al., 2011c), the trophic status (Pratt and Barreiro, 1998), the seasonal effects (Dorigo et al., 2004), the community composition (Guasch et al., 1997), the herbicide exposure level and frequency (Tlili et al., 2011), the phosphorus gradient (Tlili et al., 2010) and the current velocity (Villeneuve et al., 2011a).

To our knowledge mostly studies investigating the influence of phototrophic biofilms development stage as well thickness on its response to pollutants concern some metals (Admiraal et al., 1999; Ivorra et al., 2000; Duong et al., 2010). For organic pollutants, Guasch et al. (1997) observed that the response of phototrophic biofilms to atrazine was influenced by colonization time when experiments were carried out in winter when environmental conditions were relatively constant.

The model toxic molecule used in the present work was the alachlor herbicide [2-chloro-N-(2,6-diethylphenyl)-N(methoxymethyl) acetamide] which is extensively used as a pre-emergence chloroacetanilide herbicide applied to corn and soybeans. This molecule is detected worldwide in surface waters, at variable concentrations from less than $1 \mu \mathrm{g} \mathrm{L}^{-1}$ with peaks of several tens of $\mu \mathrm{g} \mathrm{L}^{-1}$ (Taghavi et al., 2010; Abrantes et al., 2010). Chloroacetanilide herbicides are known to inhibit the elongation of very long chain fatty acids in plants and algae (Böger et al., 2000) resulting in impaired cell development (Junghans et al., 2003; Valloton et al., 2008). To our knowledge, the toxicity of alachlor has mainly been assessed using single-species acute toxicity tests on green algae (Fairchild et al., 1997), cyanobacteria (Singh and Datta, 2005), bacteria and protozoa (Bonnet et al., 2007). A few studies showed the response of phototrophic biofilm communities to alachlor (Spawn et al., 1997; Carder and Hoagland, 1998; Pesce et al., 2011). For concentrations lower than $5 \mu \mathrm{g} \mathrm{L}^{-1}$ of alachlor, biomass growth (based on chlorophyll $a$ and ash-free dry mass (AFDM)) were inhibited and for concentrations up to $30 \mu \mathrm{g} \mathrm{L}^{-1}$ algal species composition was affected.

The main objectives of this project were to assess the sensitivity of phototrophic biofilm communities to alachlor, with regard to biofilm age and physical structure (intact biofilm versus regrown from resuspension biofilm). Firstly, phototrophic biofilms were cultivated in a prototype rotating annular bioreactor (RAB) with Taylor-Couette type flow, specifically intended for the cultivation and investigation of phototrophic biofilms and operating under constant conditions, and then used for ecotoxicological experimentation after 1.6 and 4.4 weeks of development. Ecotoxicological experiments were performed in microcosms with intact or recolonized biofilms exposed to $10 \mu \mathrm{gL}^{-1}$ of alachlor. At the end of the exposure period, the response of the communities of biofilms was assessed by a multimetric approach including both structural and functional descriptors.

\section{Material and methods}

\subsection{Phototrophic biofilm production}

Phototrophic biofilms were produced in a laboratory prototype of a rotating annular bioreactor (RAB) with Taylor-Couette type flow, as described in details by Paule et al. (2011). Initially, the bioreactor was run in batch culture mode for a seeding period to allow the micro-organisms to become attached before the continuous culture mode started. During the seeding phases, the bioreactor ran in closed recirculation, connected to an aquarium $(10 \mathrm{~L})$ where the inoculum obtained by a resuspension of natural biofilms from various river stone was incubated (Paule et al., 2011). Two seeding phases were separated by a 24 -h period where the RAB operated in continuous culture mode. The biofilm culture was investigated under controlled turbulent flowing conditions for 8 weeks. The bioreactor was continuously fed with a synthetic culture medium (the inlet throughput was $26 \mathrm{~mL} \mathrm{~min}^{-1}$ ) which consisted of tap water supplemented with nitrate, phosphate and silicate (average concentrations during the culture in the RAB water exit: $\mathrm{NO}_{3}{ }^{-}-\mathrm{N}=4.2 \mathrm{mg} \mathrm{L}^{-1}, \mathrm{PO}_{4}{ }^{3-}-\mathrm{P}=0.356 \mathrm{mg} \mathrm{L}^{-1}$, $\mathrm{SiO}_{2}=10.9 \mathrm{mg} \mathrm{L}^{-1}$, conductivity $=368 \mu \mathrm{S} \mathrm{cm}^{-1}, \mathrm{pH}=7.1$, dissolved organic carbon $-\mathrm{DOC}=1.1 \mathrm{mg} \mathrm{L}^{-1}$ ).

The inside of the RAB was illuminated by fluorescent lamps including cool daylight (Osram L15W/865 Luminux, Germany) and fluora (Osram L15W/77, Germany) tubes in equal proportions, with light/dark periods of $16 \mathrm{~h} / 8 \mathrm{~h}$ and average recorded values were $180 \pm 10 \mu \mathrm{mol} \mathrm{s}^{-1} \mathrm{~m}^{-2}$.

After 1.6 and 4.4 weeks of development in the RAB (experimental conditions called " 1.6 weeks" and " 4.4 weeks", respectively), a sampling of 9 colonized plates was carried out. Among these 9 plates from each sampling time, 6 plates were used directly for the microcosm study (experimental condition called "Plates with intact biofilm"). The last set of 3 plates was scraped with a microscope slide previously treated with $95 \%$ alcohol to ensure no trace of DNA. The biofilm from each plate was suspended in $90 \mathrm{~mL}$ of filter sterilized tap water $(0.2 \mu \mathrm{m}$ pore size filter, cellulose acetate membrane, Whatman) and homogenized (tissue homogenizer at 13,500 rpm, Ultra Turrax, T25). Each biofilm suspension homogenate was subdivided into aliquots, a first $45 \mathrm{~mL}$ subsample for the analyses of biomass descriptors (AFDM and chlorophyll $a$ ), algal abundance, T-RFLP and carbon source utilization assays (Biolog), and a second $45 \mathrm{~mL}$ subsample as inoculum source for the microcosm study (experimental condition called "recolonized biofilm").

\subsection{Microcosm setup}

The impact of alachlor on the phototrophic microbial biofilm communities, was assessed in microcosms containing either sampling plates from RAB, with an intact three-dimensional structured biofilm, or inoculated with a suspension of biofilm from a sampling plate. The microcosm system consisted of glass beakers of $500 \mathrm{~mL}$ (VWR) previously autoclaved. Moreover, the beakers used for the experimental conditions "recolonized biofilm" contained clean glass slides treated with $95 \%$ alcohol allowing to study the impact of alachlor on the development of a new biofilm. Each beaker was initially filled with $300 \mathrm{~mL}$ of a sterile synthetic culture medium similar to the culture medium feeding the RAB but with $2 \times$ concentrations of each nutrient to avoid nutrient limitation $\left(\mathrm{NO}_{3}{ }^{-}\right.$$\left.\mathrm{N}=8 \mathrm{mg} \mathrm{L}^{-1}, \mathrm{PO}_{4}{ }^{3-}-\mathrm{P}=0.6 \mathrm{mg} \mathrm{L}^{-1}, \mathrm{SiO}_{2}=30 \mathrm{mg} \mathrm{L}^{-1}\right)$. Some beakers were treated with a nominal initial concentration of $10 \mu \mathrm{g} \mathrm{L}^{-1}$ of alachlor, and others untreated were kept as controls. Alachlor purchased from Sigma-Aldrich (purity 99\%) was dissolved in acetone (analytic quality, VWR) to make a stock alachlor solution. Aliquots of this stock solution were then added to treated microcosms to 
obtain the final tested concentration. The final concentration of solvent added to each beaker was less than $0.005 \%(\mathrm{v} / \mathrm{v})$.

For each experiment in microcosm ("1.6 weeks" and "4.4 weeks") monitored for 15 days, the experimental design consisted of a treated at $10 \mu \mathrm{g} \mathrm{L}^{-1}$ alachlor and untreated intact biofilm treatments, and treated at $10 \mu \mathrm{g} \mathrm{L}^{-1}$ alachlor and untreated recolonized biofilm treatments. Each treatment supported 3 identical replicate beakers randomly. Each plate or slide represented one replicate. All the beakers were maintained in a temperature controlled $\left(20^{\circ} \mathrm{C}\right)$ chamber on a multi-post magnetic stirrer (Poly 15 , Fiers Variomag and Fisher scientific), illuminated by 4 cool daylight fluorescent tubes (F18W/GRO, Sylvania, Germany) which were positioned $30 \mathrm{~cm}$ above beakers. The system operated with $16 \mathrm{~h}$ light cycles. The illumination was measured as air PAR irradiance level by a flat quantum sensor (model LI-189, LI-COR, Inc, Lincoln, $\mathrm{NE}$ ) at a distance from the multi-post magnetic stirrer equivalent to the mid-height of a beaker ( $50 \mathrm{~cm}$ from the fluorescent tubes), the average recorded values were $37 \pm 4 \mu \mathrm{mol} \mathrm{s}^{-1} \mathrm{~m}^{-2}$. Before addition of intact biofilm plates or resuspended biofilms collected from bioreactor, the beakers were incubated for $5 \mathrm{~h}$ to obtain stable water chemical conditions.

\subsection{Experimental schedule}

To summarize, experimental conditions during the microcosm study included two biofilm development period lengths in the RAB (" 1.6 weeks" and " 4.4 weeks", giving different maturation levels of phototrophic biofilms) and two biomass structural states ("intact biofilm" and "recolonized biofilm"). Thus, the present study compares the sensitivity of biofilm communities to alachlor exposure throughout its maturation stage: either the colonization step (treatment called "recolonized biofilm") or the thickening level (treatment called "intact biofilm") associated to different development ages (after 1.6 and 4.4 weeks of development in RAB) in order to discover if the thickness of biofilm might be a protective barrier during the contamination to alachlor.

For each biofilm development period lengths in RAB, the experimental design was as follows: 6 colonized plates were sampled from the RAB and immediately transferred to 6 beakers. Moreover, each subsample of the three biofilm homogenates $(45 \mathrm{~mL})$, after centrifugation $\left(12,000 \times \mathrm{g}\right.$ for $20 \mathrm{~min}$, at $\left.4{ }^{\circ} \mathrm{C}\right)$, was resuspended into 6 or $8 \mathrm{~mL}$, then subdivided and equally inoculated $(3-4 \mathrm{~mL})$ into a total of 6 other beakers which contained the glass slides previously cleaned with alcohol $90 \%$. Thus the amount of resuspended biofilm homogenate inoculated into beakers gave average final concentrations at day 0 of 15 and $45 \mathrm{mg} \mathrm{AFDM} \mathrm{L}^{-1}$ from 1.6 and 4.4 weeks biofilm ages, respectively. For each experimental condition (biofilm and suspension), each group of 6 beakers included 3 replicate control beakers without alachlor and 3 replicates with alachlor $10 \mu \mathrm{g} \mathrm{L}^{-1}$. All the beakers were closed with the lid of a Petri dish. A window was performed on the middle of the lid to allow the glass slides and plates to be inserted and maintained vertically in the beakers. The loss of water volume by evaporation was compensated by addition of distilled water.

At the end of experiments (15 days), all glass slides (6 slides corresponded to 3 replicates for each treated and untreated microcosm) and plates (6 plates corresponded to 3 replicates for each treated and untreated microcosm) were sampled to assess the intact (from plates) and reformed biofilm (from glass slides) response to alachlor exposure. Biofilms were removed from plates and slides by scraping as described above. Biofilms were suspended in $50 \mathrm{~mL}$ (biofilm from slides) or $90 \mathrm{~mL}$ (biofilm from plates) of tap water previously filtered through a $0.2 \mu \mathrm{m}$ pore size filter (cellulose acetate membrane, Whatman) and homogenized (tissue homogenizer at $13,500 \mathrm{rpm}$, Ultra Turrax, T25). From these homogenates (50 or $90 \mathrm{~mL}$ ), aliquots were taken for analyses of biomass descriptors, algal and diatom composition, bacterial community structure, and carbon source utilization profiles assays.

Water samples $(70 \mathrm{~mL})$ from each microcosm were collected after 5 days of incubation and at the end of incubation to evaluate the alachlor residual concentrations and the water physicochemical characteristics.

\subsection{Water physico-chemical parameters}

Nutrient concentrations during the culture in RAB and ecotoxicological experiments, including nitrates, silica, and orthophosphates, and DOC concentrations were measured as described by Paule et al. (2009, 2011). Conductivity (and temperature) and pH values were measured with a conductimeter Hanna HI 991300 and a pH meter 320WTV (electrodes Sentix41), respectively. Dissolved oxygen concentrations were determined with an Oxi323 oxymeter (electrodes oxical-S).

Dissolved oxygen concentrations, $\mathrm{pH}$, temperature and conductivity values during the culture in RAB were measured at the water outlet valve of the reactor as described by Paule et al. (2011).

For the measurement of residual alachlor concentrations, the water samples $(5 \mathrm{~mL})$ were filtered through Whatman $\mathrm{GF} / \mathrm{F}$ glass fibre filters $(0.7 \mu \mathrm{m}$ pore size) and analyzed at "Laboratoire Départemental de l'Eau" (Toulouse, France), using high performance liquid chromatography coupled tandem to mass spectrometry (HPLC-MS-MS, Thermo Fisher, model E-Quan TSQ Quantum ultra) with ionization electron spray source and equipped with a pre-concentration column (Thermo Fisher Hypersil GOLD $\mathrm{C} 18,12 \mu \mathrm{m}$ particle size, $20 \times 2.1 \mathrm{~mm}$ ), by a direct sample injection. The sample volume was $2 \mathrm{~mL}$. The alachlor separation was monitored using a Thermo Fisher Hypersil GOLD C18 ( $3 \mu \mathrm{m}$ particle size, $50 \times 2.1 \mathrm{~mm}$ ) column.

\subsection{Biofilm characterization}

\subsubsection{Biomass descriptors}

From the biofilm suspension homogenate, AFDM (aliquot from 10 to $50 \mathrm{~mL}$ ), and chlorophyll $a$ were measured as described by Paule et al. (2009).

\subsubsection{Algal composition}

Diatom composition of biofilms cultivated in the RAB (sampled at 1.6 and 4.4 weeks) and at the end of the ecotoxicological experiments was estimated from aliquots of the biofilm suspension homogenates $(5 \mathrm{~mL})$, preserved in formalin solution $(3 \%)$ and kept in darkness at $4{ }^{\circ} \mathrm{C}$ until analysis. Identification and counting of 400 diatom frustules were performed as described previously by Roubeix et al. (2011a). Taxonomic identifications for all species were checked from the taxonomic literature of Central Europe and recent nomenclature updates (see Table S1 in the supplementary material to access to the links from different Data bases referring to image for each indentified diatom species).

As proposed by Pappas and Stoermer (1996), the efficiency for counting our samples (diatoms community with a maximum of 12 species) with 400 diatom frustules is comprised between 0.968 and 0.98 .

For the biofilms sampled in the RAB after 1.6 and 4.4 weeks of culture, algal composition was estimated from a pool of aliquots of $5 \mathrm{~mL}$ clustering biomasses from 3 plates. The total density and abundance percentages were determined with an inverted microscope (Axiovert 10, Zeiss, West Germany) (Utermöhl, 1958).

\subsubsection{Carbon source utilization profiles}

Community level analysis of carbon source utilization profiles for all experimental conditions were evaluated by using commercial Eco-plates (Biolog, Hayward, CA, USA). Each microplate 


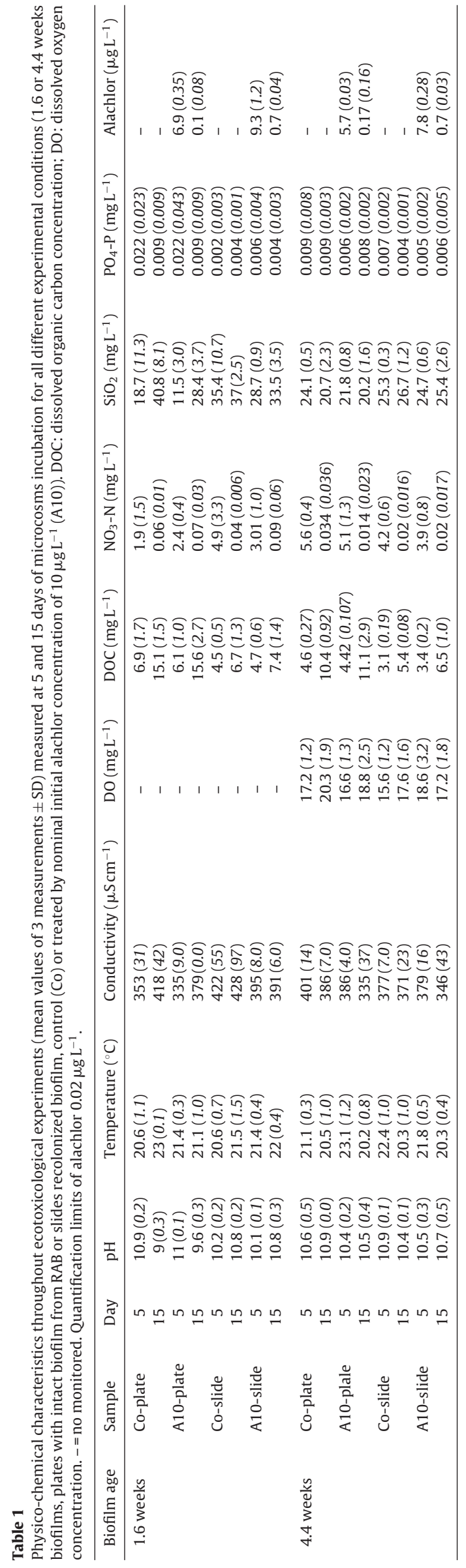

was inoculated with $100 \mu \mathrm{L}$ of an aliquot of biofilm suspension homogenate $(5 \mathrm{~mL})$ previously filtered on polycarbonate filter ( $0.3 \mu \mathrm{m}$ pore size, GS $25 \mathrm{~mm}$, Whatman) and then incubated in the dark at $20^{\circ} \mathrm{C}$ for 7 days. Each microplate was used for one experimental condition (3 replicates). The absorbance was measured every day at $590 \mathrm{~nm}$ using a multi well plate reader (Spectro Max plus 384, Molecular Device). For every absorbance value, the controls were subtracted. For statistical analysis, the net absorbances at $168 \mathrm{~h}$ of incubation were used. The substrates were grouped by guild following their chemical structure (Choi and Dodds, 1999): amines, amino acids, carbohydrates, carboxylic acids, polymers and phenolic compounds. As described by Leflaive et al. (2005), a principal component analysis (PCA) was conducted on the guild categorization.

\subsubsection{Bacterial community structure}

After centrifugation $\left(12,000 \times g\right.$ at $4{ }^{\circ} \mathrm{C}$ for $20 \mathrm{~min}$, Heraeus Multifuge) of an aliquot of $20-50 \mathrm{mg}$ dry mass of the biofilm suspension homogenate (Lyautey et al., 2005a), the pellet was stored at $-80^{\circ} \mathrm{C}$ until further analysis. Genomic DNA extraction was performed on the pellet using a DNeasy Plant Mini Kit according to the manufacturer's protocol (Qiagen Laboratories). The integrity of the extracted DNA was checked as described by Paule et al. (2009).

The 16S rRNA genes were amplified by PCR and the bacterial community structure was studied by T-RFLP as described by Paule et al. (2011). Restriction digestion was performed with HaeIII, Hinfl and Hpa. T-RFLP profiles were aligned by a web-based tool, T-Align (http://inismor.ucd.ie/ talign/) as previously described by Smith et al. (2005) with a confidence interval of 0.5.

\subsection{Data analysis}

The difference in physico-chemical characteristics and the difference in AFDM, chlorophyll $a$, the number of diatoms deformities and the number of T-RFs between biofilm samples were assessed with the Mann-Whitney test using SPSS software 13.0. Differences were considered statistically significant at $p \leq 0.05$.

To assess changes in the bacterial community structure in microcosms, a PCA was performed from the log-transformed T$\mathrm{RF}$ abundance data. A hierarchical cluster analysis was performed based on Bray Curtis similarity matrices generated from the log-transformed diatom abundance. PCA and hierarchical cluster analyses were realized on the samples clustered following biomass structure state (intact biofilm versus recolonized biofilm) using Primer v6 software (PrimerE, Ltd, Lutton, United Kingdom). Peaks $<0.5 \%$ of the total area were excluded from the analysis and T-RFs that differed in size by 0.5 bp or less were considered to be identical.

This baseline of $0.5 \%$ was defined in accordance with the approaches of Osborne et al. (2006). Statistical analyses of PCA were run using an analysis of similarity (ANOSIM) via primer v6 software on Bray Curtis similarity matrices generated from log-transformed T-RF abundance or guild categorization data (Clarke, 1993). The global $R$ value was considered statistically significant at $p<0.05$ uncorrected.

\section{Results}

\subsection{Characterization of phototrophic biofilms collected in $R A B$}

The 1.6 weeks-old biofilm exhibited lower AFDM and chlorophyll $a$ values $\left(1.12 \pm 0.28 \mathrm{mg} \mathrm{cm}^{-2}\right.$ and $6.2 \mu \mathrm{g} \mathrm{cm}^{-2}$ for AFDM and chlorophyll $a$, respectively) than 4.4 weeks-old biofilm $\left(2.45 \pm 0.30 \mathrm{mg} \mathrm{cm}^{-2}\right.$ and $31.7 \mathrm{mg} \mathrm{cm}^{-2}$ for AFDM and chlorophyll $a$, respectively) ( $p>0.05)$ (Fig. 1, for T0 conditions). The 1.6 weeksold biofilm was composed of 33\% Diatoms, 51.7\% Chlorophyceae, and $14.9 \%$ Cyanobacteria with the following dominant phototrophic 

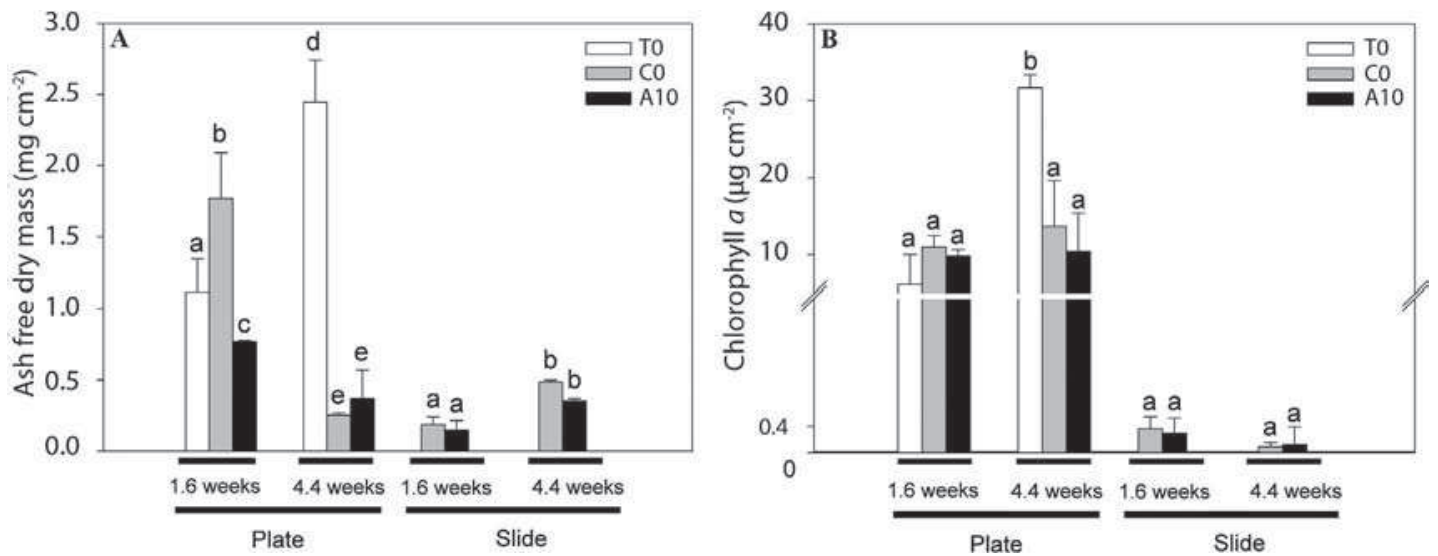

Fig. 1. Plots of AFDM (A) and chlorophyll $a(B)$ values ( \pm SD, $n=3$ ) after 15 days of incubation in the control (Co) and exposed to nominal initial alachlor concentration of $10 \mu \mathrm{L} \mathrm{L}^{-1}$ (A10) microcosms according to the different experimental conditions (1.6 and 4.4 weeks: ages of biofilms when collected in the RAB; plates with intact biofilm from RAB or slides recolonized biofilm). "T0" indicated the date where fresh biofilm plates were sampled after 1.6 and 4.4 weeks of biofilm development in the RAB.

taxa at the genus level: $31.5 \%$ of Nitzschia, $28 \%$ of Scenedesmus and Desmodesmus and $13 \%$ of Lyngbya spp. In contrast, 4.4 weeks-old biofilm was composed of $4.1 \%$ Diatoms (only Nitzschia) and $95.5 \%$ Chlorophyceae with the dominant species $74.9 \%$ of Scenedesmus. Moreover the 1.6 weeks-old biofilms exhibited higher specific algal richness (13) than the 4.4 weeks-old biofilms (7)

\subsection{Physico-chemical parameters in microcosms}

Physico-chemical parameters measured in water samples from control and alachlor treated microcosms during both ecotoxicological experiments are presented in Table 1. Values of $\mathrm{pH}$ and conductivity were relatively homogenous throughout the experiment irrespective of the experimental conditions. Although, a decrease of nitrate and orthophosphate levels was recorded, an increase in DOC was detected throughout the times of incubation. Similarly, a reduction of residual alachlor concentration was observed over time. Observations are similar between both experiments " 1.6 weeks" and " 4.4 weeks". The time-weighted average concentration (TWAC), defined as the sum of the mean alachlor concentration in the exposure medium at each measured time interval multiplied by that time interval and divided by the total time of observation, give a mean value of $5.52 \pm 0.74 \mu \mathrm{g} \mathrm{L}^{-1}$ for all the experiments (TWAC varied from 4.6 to $6.5 \mu \mathrm{g} \mathrm{L}{ }^{-1}$ ), with a nominal initial alachlor concentration of $10 \mu \mathrm{g} \mathrm{L}^{-1}$.

\subsection{Phototrophic biofilms response to alachlor exposure in} microcosms

\subsubsection{Biomass descriptors}

Fig. 1 presents the impact of alachlor exposure on the biomass descriptors (AFDM and chlorophyll a) for the different experimental conditions. The intact biofilms sampled in the control and alachlor treated microcosms at the end of both experiments " 1.6 weeks" and " 4.4 weeks" exhibited AFDM values ranged from 0.25 to $1.75 \mathrm{mg} \mathrm{cm}^{-2}$ and chlorophyll $a$ values ranged from 9.5 to $13.5 \mu \mathrm{g} \mathrm{cm}^{-2}$. Although the recolonized biofilms from slides exhibited AFDM values ranged from 0.15 to $0.45 \mathrm{mg} \mathrm{cm}^{-2}$ and chlorophyll $a$ values ranged from 0.05 to $0.1 \mu \mathrm{g} \mathrm{cm}{ }^{-2}$.

Alachlor induced significant effects on AFDM for the experimental conditions "1.6 weeks and Plates with intact biofilm" (Mann-Whitney, $p<0.05$ ), associated with processes of loss of biomass and/or inhibition of growth (Fig. 1A). No significant effect of alachlor was observed on chlorophyll $a$ irrespective of the structural state of biomasses (intact biofilm or recolonized biofilm) (Mann-Whitney, $p>0.05$ ) (Fig. 1B). Biofilms of the experimental conditions " 4.4 weeks and Plates with intact biofilm" sampled at the end of the microcosm experiment exhibited high loss of biomass (AFDM and chlorophyll $a$ ) irrespective of exposure to alachlor and control microcosms related to the temporal evolution of intact biofilm $(p<0.05)$.

\subsubsection{Bacterial communities}

The response of bacterial communities from phototrophic biofilms exposed to alachlor according to its level of maturation and structural state were determined by T-RFLP. No significant alachlor effect was observed on the T-RFs numbers irrespective the experimental conditions (data not shown) $(p>0.05)$. Principal component analysis (PCA) was performed on the T-RF log-transformed abundance data according to the structural state of biomasses incubated at the start of experiments (Fig. 2). The two axes accounted for 44.4 and $17.8 \%$ of the total variance for the experimental condition "Plates with intact biofilm" (Fig. 2A) and for 54.8 and $12 \%$ for the experimental condition "Slides recolonized biofilm" (Fig. 2B). This analysis was strengthened by the similar trends observed with PCAs scatterplot figured between the first and third axes. The first three axes accounted for 74.7 and $71.5 \%$ of the variation of T-RFLP patterns for both experimental conditions "Plates with intact biofilm" and "Slides recolonized biofilm", respectively (data not shown).

For the experimental condition "Plates with intact biofilm" (Fig. 2A), PCA shows temporal variations of bacterial communities from 1.6 weeks-old biofilm during the microcosm study (ANOSIM, global $R=1, p=0.01$ ). However, no temporal variation was observed for the 4.4 weeks-old biofilm incubated on plates. For the experimental condition "Slides recolonized biofilm" (Fig. 2B), the profiles of bacterial community structure were distributed according to the maturation level of biofilms incubated (1.6 versus 4.4 weeks) (ANOSIM, global $R=0.981, p=0.01$ ).

No change of the bacterial community structure was induced by the alachlor exposure compared to the control, irrespective of the maturation level (1.6 and 4.4 weeks) and the structural state of biomasses (intact biofilm or recolonized biofilm), respectively (Fig. 2A, ANOSIM, global $R=0.122, p=0.25$ ) (Fig. 2B, ANOSIM, global $R=-0.093, p=0.71$ ).

\subsubsection{Carbon source utilization profiles}

PCAs were performed on the guild categorization according to the structural state of biomasses (intact biofilm or recolonized biofilm) (Fig. 3). The two axes accounted for 62.6 and 18.3\%, and 77.2 and $13.2 \%$ of the total variance for the "Plates with intact biofilm" and for the "Slides recolonized biofilm", respectively. This analysis was strengthened by the similar trends observed with 
A

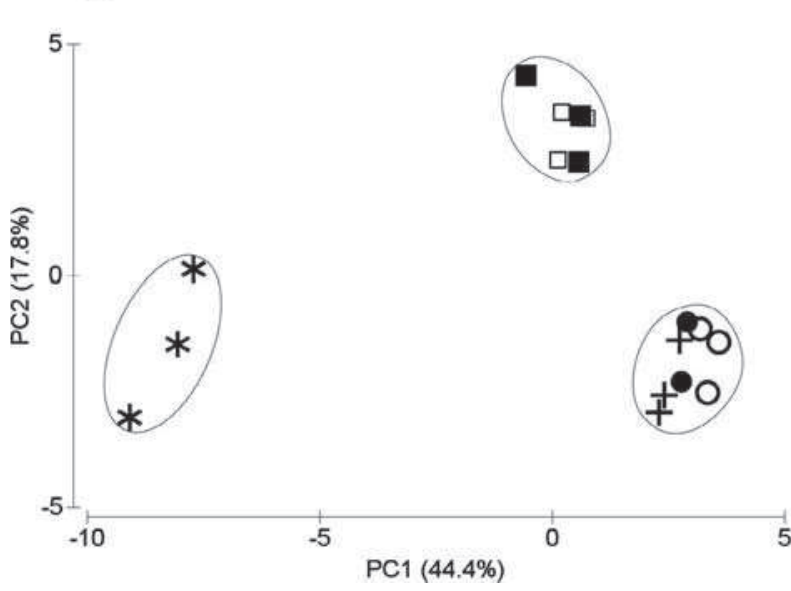

B

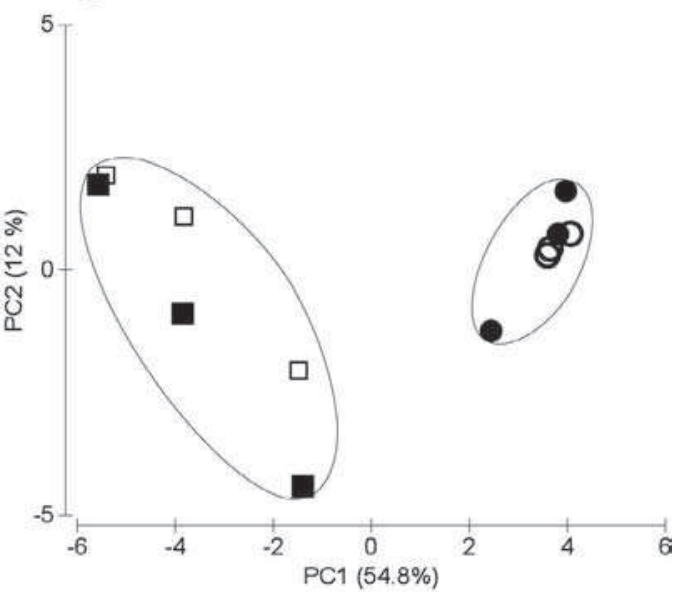

Fig. 2. Changes in the bacterial community structure assessed by principal component analysis (PCA) based on the T-RFLP data after 15 days of incubation in the control (white symbols $\square$ and $\bigcirc$ ) and exposed to nominal initial alachlor concentration of $10 \mu \mathrm{g} \mathrm{L}^{-1}$ (black symbols $\boldsymbol{\square}$ and $\boldsymbol{\bullet}$ ) microcosms according to the different experimental conditions, 1.6 weeks (squares $\square$ and $\mathbf{\square}$ ) and 4.4 weeks (circles $\bigcirc$ and $\bullet$ ) biofilms; plates with intact biofilm from RAB (A) or slides recolonized biofilm (B). Symbols "star" and "cross" in (A) design the results for fresh biomasses sampled after 1.6 and 4.4 weeks of biofilm development in the RAB, respectively. Circles correspond to a similarity between samples of $70 \%$.

PCAs scatterplot figured between the first and third axes. The first three axes accounted for 90.2 and $95 \%$ of the variation of Biolog patterns for the conditions "Plates with intact biofilm" and "Slides recolonized biofilm", respectively (data not shown).

No significant effect of alachlor was observed on the carbon source utilization profiles irrespective of the different experimental conditions considered (Fig. 3A, ANOSIM, global $R=0.093, p=0.2$ ) (Fig. 3B, ANOSIM, global $R=0.278, p=0.9$ ). For the biofilms of the experimental condition "Slides recolonized biofilm", the communities from 1.6 weeks-old biofilm exhibited a tendency to use the carboxylic acids and carbohydrates while the communities from 4.4 weeks-old biofilm appeared to preferentially use the amines and phenolic compounds (Fig. 3B).

In agreement with the analysis of bacterial community structure (Fig. 2), the PCA according to the experimental condition "Plates with intact biofilm" showed temporal variations of bacterial communities from 1.6 weeks-old biofilm through incubation accompanied by changes in the preferential utilization of carbon source (Fig. 3A). Conversely, no significant temporal variation was observed for the bacterial communities from 4.4 weeks-old biofilm.

\subsubsection{Diatom communities}

For the experimental condition "Plates with intact biofilm", senescence of the biofilms samples from 4.4 weeks-old biofilm prevented the counting and identification of the diatom species because of a too low preservation of the frustules. Data from these samples were thus not included in the analysis (Fig. 4 and Table 2). A total of 12 diatom species identified throughout the microcosm experiments had a relative abundance $>1 \%$, and were considered as characteristic of each diatom community (Fig. 4). For the diatom communities of the experimental condition "Slides recolonized biofilm" (Fig. 4B), compositions were divergent depending on maturation level of biofilms incubated (1.6 and 4.4 weeks) (ANOSIM, global $R=1, p=0.01$ ). The diatom communities from 1.6 weeksold biofilm were mainly composed of Nitzschia palea (Kützing) W. Smith (NPAL), Nitzschia amphibia Grunow f. amphibia (NAMP) and Eunotia minor (Kützing) Grunow in Van Heurck (EMIN), and the communities from 4.4 weeks-old biofilm were essentially composed of NAMP and NPAL associated with different proportions (Table 2 and Supplementary material for the link of image for each diatom species). Diatom communities which were collected at the end of microcosm experiment exhibited no significant change induced by alachlor exposure, irrespective of the structural state and the maturation level of the biofilms incubated at the start of microcosm experiment (experimental condition "Plates with intact biofilm": ANOSIM, global $R=0.185, p=0.14$ ) (experimental condition "Slides recolonized biofilm": ANOSIM, global $R=0.074, p=0.5$ ). For the experimental condition "Plates with intact biofilm", no temporal variation was observed through incubation, with diatom communities mainly composed of NPAL (82-87\%) (Table 2). No significant abnormal forms of diatoms were observed in response to alachlor treatments (data not shown).

\section{Discussion}

The objectives of the present study were to assess alachlor toxicity on microbial communities of phototrophic biofilm in relation to age and state (intact versus recolonized biofilm). Phototrophic biofilm grown in RAB under stable operating conditions was preferred to the use of natural phototrophic biofilms collected in situ. In $R A B$, the growth of biofilm was mainly driven by autogenic factors, favouring the development of simplified biofilms structures with low algal diversity (Paule et al., 2011). The choice of development times ("1.6 and 4.4 weeks") was based on the observations on phototrophic biofilm growth reported in a previous study (Paule et al., 2011). During the microcosm alachlor exposure experiments, factors which influence the growth of phototrophic biofilms were maintained constant (light, temperature and hydrodynamic), thus the difference recorded between controls $(\mathrm{Co})$ and alachlor-treated (A10) microcosms are attributable to alachlor. Levels of alachlor in the treated microcosms decreased over time for both experiments ("1.6 and 4.4 weeks") with a pseudo-half-life of $4.2 \pm 0.1$ and $2.8 \pm 0.8$ days for slides and plates experiments, respectively, and a mean TWAC of $5.52 \pm 0.74 \mu \mathrm{g} \mathrm{L}^{-1}$. The current study exhibited lower half-life values than those recorded in previous studies which range from 9.7 to 180 days (Graham et al., 1999, 2000; Ensz et al., 2003; Knapp et al., 2003). However, they are consistent with the half-life values recorded for sediment-water systems containing higher biomass levels (Laabs et al., 2007). Numerous mechanisms could be involved in the disappearance of alachlor within our microcosms including photodegradation, hydrolysis, adsorption (on the biofilm or microcosm materials), biosorption (internalization in microbial cells), and volatilization mechanisms (Chesters et al., 1989), although previous studies in aquatic systems suggest 

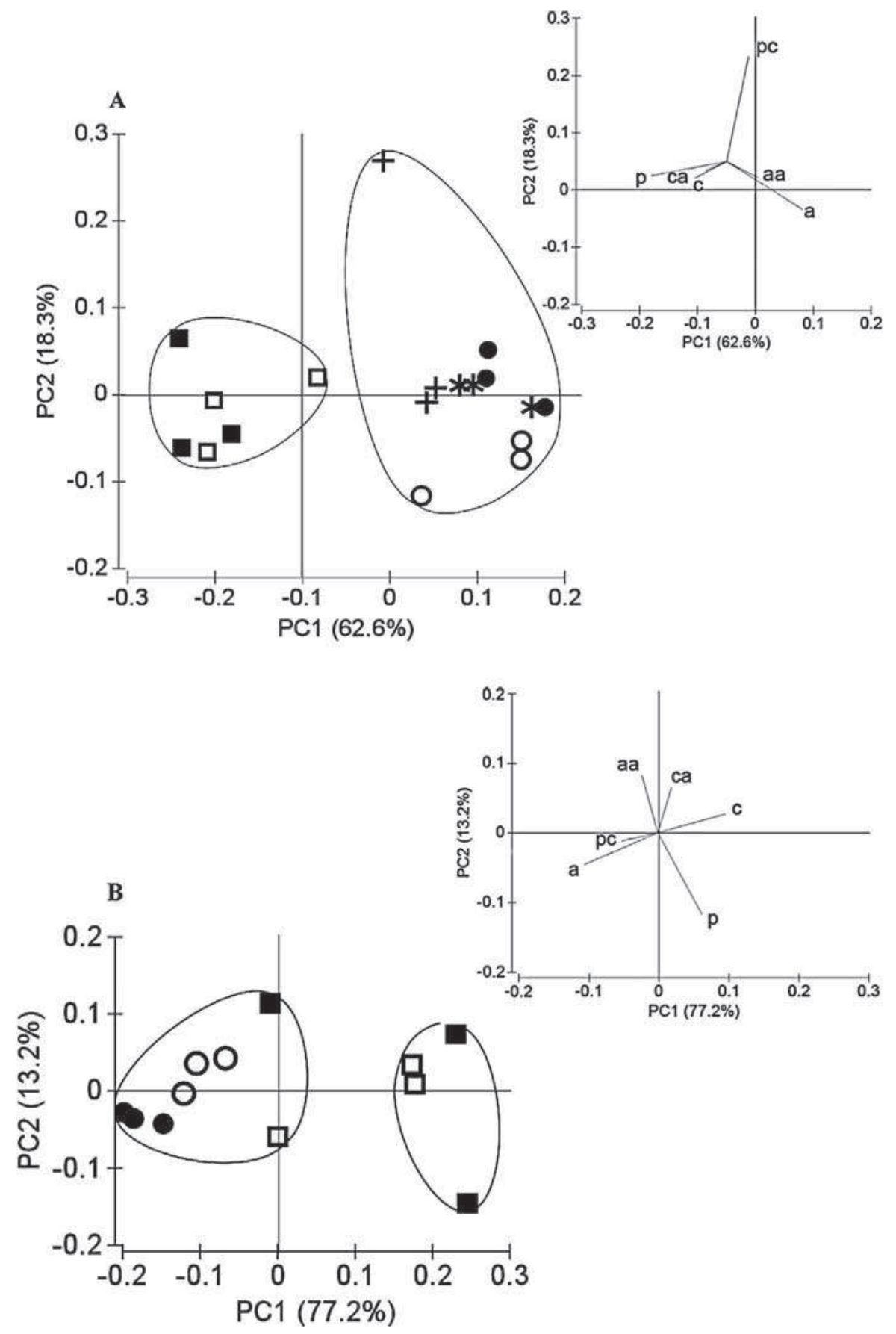

Fig. 3. Results of the principal component analysis (PCA) carried out on the carbon source group utilized (net optical density at $168 \mathrm{~h}$ ) by microbial communities after 15 days of incubation in the control (white symbols $\square$ and $\bigcirc$ ) and exposed to nominal initial alachlor concentration of $10 \mu \mathrm{g} \mathrm{L}^{-1}$ (black symbols $\mathbf{\square}$ and $\mathbf{\text { ) }}$ ) microcosms according to the different experimental conditions (1.6 weeks (squares $\square$ and $\mathbf{\square}$ ) and 4.4 weeks (circles $\bigcirc$ and $\bullet$ ) biofilms; plates with intact biofilm from RAB (A) or slides recolonized biofilm (B). Symbols "star" and "cross" design the results for fresh biomasses sampled after 1.6 and 4.4 weeks of biofilm development in the RAB, respectively. Big circles correspond to a similarity between samples of 70\%. For (A) and (B), projection of the variables (carbon source guild) on the component planes with a: amines; aa: amino acids; c: carbohydrates; ca: carboxylic acids; p: polymers; pc: phenolic compounds.

that the key mechanism of disappearance of alachlor is biotransformation catalyzed by the non-specific Glutathione S-transferase (GST) enzyme (e.g. Graham et al., 2000). In the hypothesis of biodegradation processes, the results could be the presence of alachlor metabolites (e.g. alachlor OA - oxanilic acid; alachlor ESA - ethane sulfonic acid). Previous study on other chloroacetanilide herbicides recorded a lower toxicity of the metabolites compared to that of their parent compounds (Roubeix et al., 2012).

\subsection{Alachlor toxicity throughout development stages}

The chloroacetanilide herbicides are well known to inhibit the elongation of unsaturated chain fatty acid in plants and algae (Böger et al., 2000), thus inhibiting cell development (Junghans et al., 2003). No significant change caused by the alachlor exposure for 15 days at mean TWAC of $5.52 \pm 0.74 \mu \mathrm{g} \mathrm{L}^{-1}$ was observed in the present study in terms of bacterial and diatom community structures and carbon source utilization profiles irrespective 


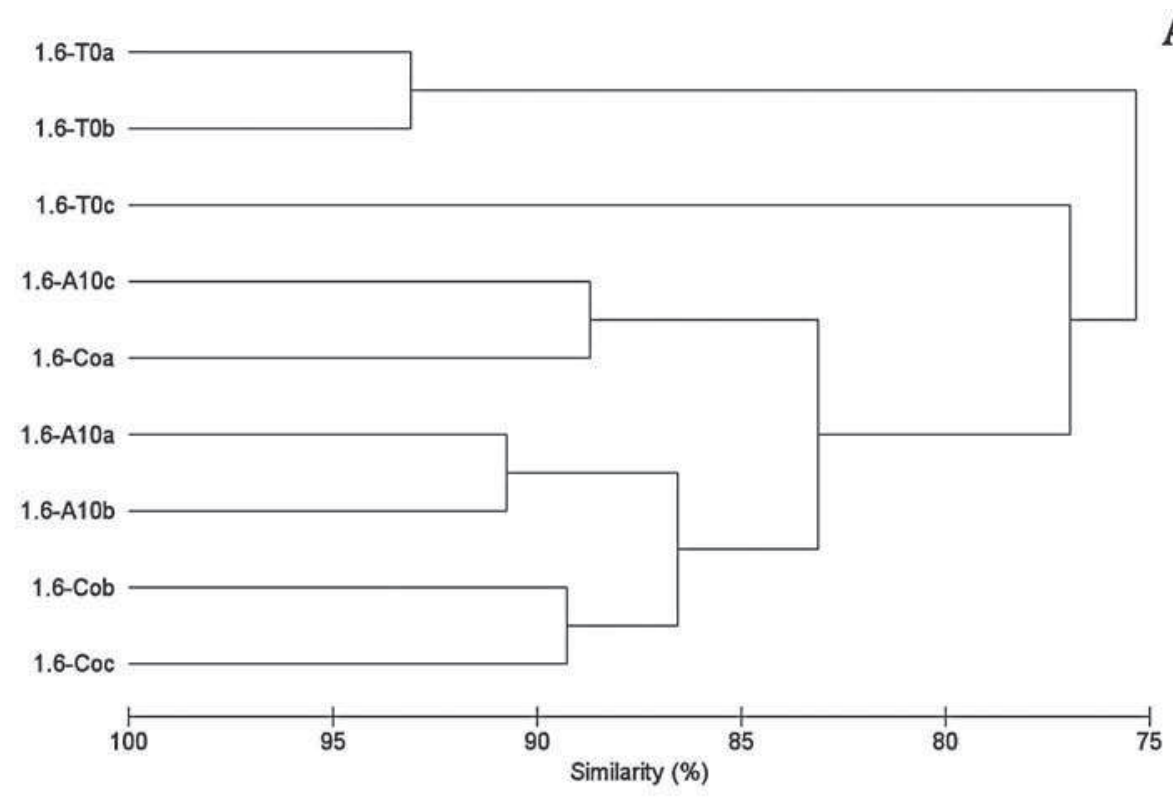

A

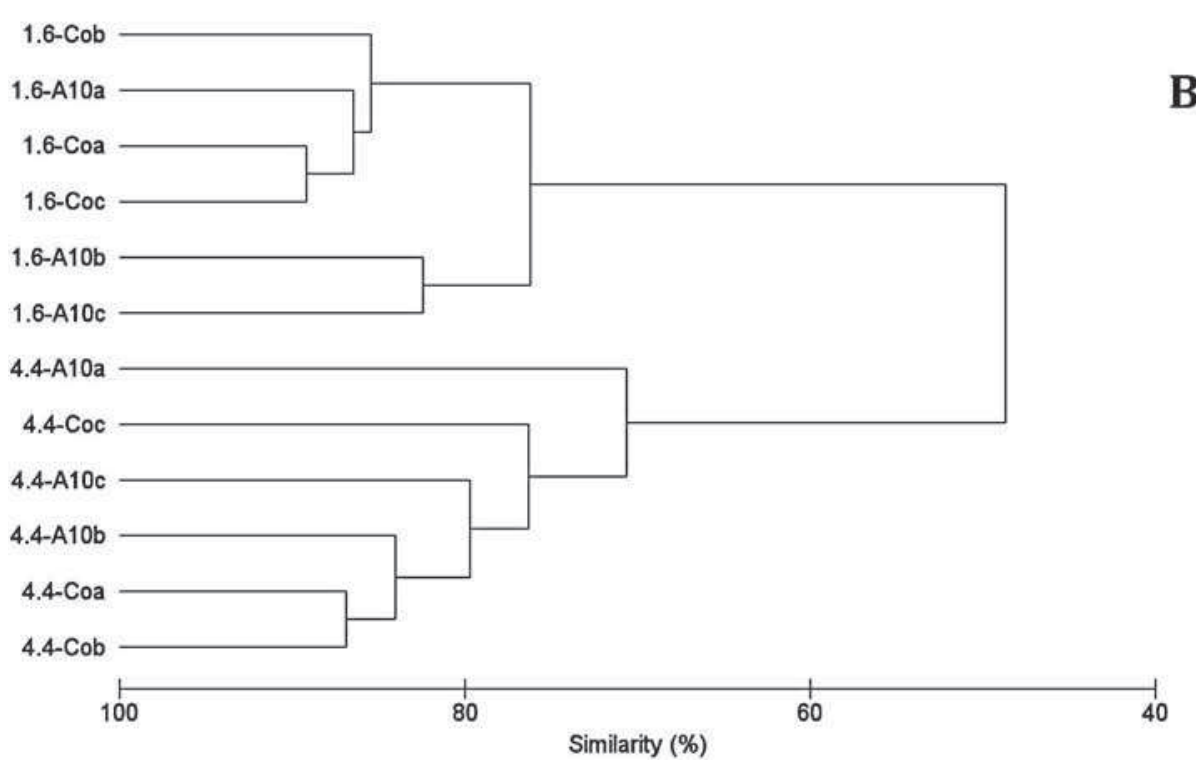

Fig. 4. Cluster of the similarity in taxonomic composition of diatom communities after 15 days of incubation in the control (Co) and exposed to nominal initial alachlor concentration of $10 \mu \mathrm{g} \mathrm{L}^{-1}$ (A10) microcosms according to the different experimental conditions 1.6 weeks (1.6) and 4.4 weeks (4.4) biofilms; plates with intact biofilm from $\mathrm{RAB}(\mathrm{A})$ or slides recolonized biofilm (B). "T0" indicated the date where fresh biofilm plates were sampled after 1.6 weeks of biofilm development in the RAB. The letters a, b and $\mathrm{c}$ indicate replicates from same experimental condition.

the development stages. Moreover no diatom frustules exhibited a significant number of deformities $(p>0.05)$. Only the biomass based on AFDM results was impacted for the condition " 1.6 weeks and Plates with intact biofilm" which is consistent with the processes of growth inhibition. Furthermore, the absence of change in the structure evaluated by T-RFLP and physiological states evaluated by Biolog of bacterial communities would indicate that some functions of biofilm are not damaged resulting in unperturbed overall ecosystem functioning. Previous results (Spawn et al., 1997) described a significant negative effect on the chlorophyll $a$ levels for alachlor concentrations of $10 \mu \mathrm{g} \mathrm{L}^{-1}$, and changes in dominant algal composition at higher level of alachlor $\left(30 \mu \mathrm{g} \mathrm{L}^{-1}\right)$. Algal community bio-volume was impacted throughout experiments in streams treated with alachlor at $90 \mu \mathrm{g} \mathrm{L}^{-1}$ (Carder and Hoagland, 1998).

Ecologically, this reduction of the amount of biomass (AFDM) could impair the quality of biofilm as a food resource for aquatic grazers, and change the community contribution to organic matter mineralization and element recycling. Furthermore, the absence of change in the structure evaluated by T-RFLP and physiological states evaluated by Biolog of bacterial communities would indicate that some functions of biofilm are not damaged resulting in unperturbed overall ecosystem functioning.

To our knowledge, few studies have investigated the toxicity of alachlor at a community-level using phototrophic biofilms (e.g. Spawn et al., 1997; Carder and Hoagland, 1998). However, studies have explored the impact of metolachlor, metazachlor or acetochlor, chloroacetanilide herbicides which share a similar mode of action than alachlor (e.g. Noack et al., 2004; Relyea, 2009; Debenest et al., 2009; Roubeix et al., 2011a, 2012). For example, previous studies observed that metolachlor and metazachlor generated growth inhibition suggested by lower chlorophyll $a$ levels of phototrophic biofilms exposed at 5 and $30 \mu \mathrm{g} \mathrm{L}^{-1}$ (Noack et al., 2004; Debenest et al., 2009). Conversely, Roubeix et al. (2011a) did not detect any significant effect on the biomass (AFDM and 


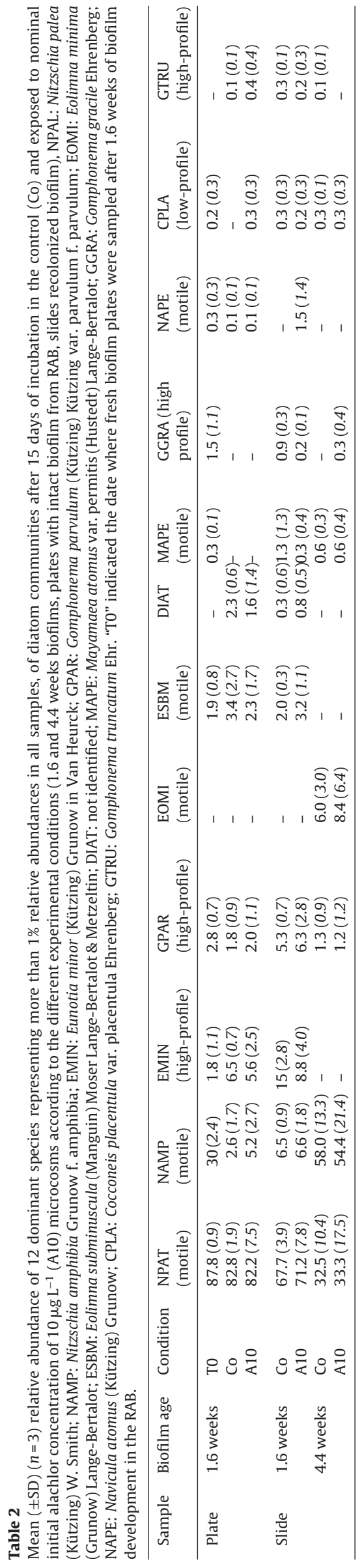

chlorophyll a) of biofilms exposed to metolachlor at 5 and $30 \mu \mathrm{g} \mathrm{L}^{-1}$ for 14 days but recorded significant difference between the control and exposed diatom communities in terms of species composition. Furthermore, previous works demonstrated the occurrence of frustule and cellular deformations in diatoms and green algae at high concentrations of metolachlor $\left(30 \mu \mathrm{g} \mathrm{L}^{-1}\right)$ (Liu and Xiong, 2009; Roubeix et al., 2011a). Short-assays for $96 \mathrm{~h}$ on the impact of acetochlor on freshwater bacterial communities revealed dosedependent impact on their structure, evident in the development of three distinct dose dependent clusters $\left(0,1\right.$ and $5 \mu \mathrm{g} \mathrm{L}^{-1} ; 50$ and $100 \mu \mathrm{g} \mathrm{L}^{-1}$ and $500 \mu \mathrm{g} \mathrm{L}^{-1}$ ) and, an increase in the number of carbon sources utilized which may illustrate an increased functional diversity (Foley et al., 2008).

Tolerance of bacterial and diatom communities to alachlor observed in the present study irrespective of the treatment may be explained by (i) the environmental context suggesting the presence of tolerant species in biofilms collected in the RAB and initially present in the inoculum (epilithic biofilms from various river stones), (ii) a first perturbation during the exposure by changing the operating conditions (including nutrient concentrations, illumination, hydrodynamic conditions and resuspension), because communities which previously seem to have been impacted by other stresses often respond weakly to a second stress (Tlili et al., 2008), (iii) a shorter exposure period associated with the fast disappearance of alachlor over time in aqueous phase, giving a TWAC lower than the nominal initial concentration, (iv) for intact biofilm, its thickness which may act as a protective barrier limiting transfers with the water column (Wicke et al., 2008), (v) a natural ecological succession of communities, in other terms the influence of autogenic factors dominating allogenic factors associated with reduced exchanges between micro-organisms and water column compared to micro-organism interactions inside aggregates, and (vi) a low toxicity of chloroacetanilide herbicides linked to their mode of action or the ability of micro-organisms to biodegrade by co-metabolisms reactions catalyzed by non-specific GST enzyme (Debenest et al., 2009).

It is interesting to observe that the thin biofilms developing over 15 days on the slides (corresponding to the first stage of biofilm development) from the resuspended biofilms, did not exhibit higher sensitivity to alachlor. It has been suggested that the thickness of biofilm could provide better protection against alachlor, decreasing diffusion barrier slowing transfers (Villeneuve et al., 2011 b). The growth of phototrophic biofilms may be higher influenced by factors such as the use of artificial supports (Kröpfl et al., 2006; Lane et al., 2003; Murdock and Dodds, 2007) or nutrientrich medium used during the experiment (Hillebrand and Sommer, 2000), thus masking the potential effects of alachlor. Noack et al. (2004) observed that the growth of biofilm was influenced by both the presence of metazachlor and the ability of species to grow on artificial supports.

Jurgensen and Hoagland (1990) observed that changes in hydrodynamic conditions had a greater impact on phototrophic biofilms relative to pulsed atrazine exposures. In the present study, the state of first stage of biofilm development which suggest the most water column - biofilm interactions seems to be the less affected by the presence of herbicide.

\subsection{Influence of phototrophic biofilm environmental context on the response to alachlor}

The bacterial and algal species composition, the thickness, compactness and elasticity of the three-dimensional structure and the functions of biofilms are mediated by their environmental context (e.g., light, nutrient, current velocities). Previous studies concluded that biofilms growing under fast current conditions presented a 
more compact structure (Battin et al., 2003). Most importantly, it has been reported that phototrophic biofilms exhibiting elastic three-dimensional architecture are more sensitive to pesticide than phototropic biofilms exhibiting compact structure (Guasch et al., 2003). The nature elastic or compact of three-dimensional architecture of biofilm is depending on present algae species. Zippel and Neu (2005) concluded that green-algal dominated biofilms presented a less stable and compact structure. In the present study, Chlorophyceae represented 51.7 and $95.5 \%$ of the algal taxa abundance for the 1.6 and 4.4 weeks-old biofilms, respectively.

A review about the impact of herbicides on freshwater microbial communities suggested the importance of initial composition of communities in the response of biofilm to herbicide exposure (Villeneuve et al., 2011c). Chloroacetanilide herbicides disturb the elongation of very long chain fatty acids. Thus the membranes lose their rigidity and permeability, leading to impaired cell division. Mohr et al. (2008) studied the effects of metazachlor on the response of phytoplankton and suggested that the sensitivity of algal species may be due to the presence of very long chain fatty acids in their membrane.

Algal communities present in the biofilms initially collected from the RAB are dominated by green algae such as Scenedesmus, Desmodesmus and diatoms including Nitzschia palea (Kützing) W. Smith. Published toxicity data for alachlor using Scenedesmus species show $\mathrm{EC}_{50}$ varied greatly from 6 to $1328 \mu \mathrm{g} \mathrm{L}^{-1}$ depending on species (Desmodesmus quadricaudatus $1328 \mu \mathrm{g} \mathrm{L}^{-1}$, Fairchild et al., 1998; Scenedesmus vacuolatus $37.8 \mu \mathrm{g} \mathrm{L}^{-1}$, Junghans et al., 2003; and Selenastrum capricornutum $6 \mu \mathrm{g} \mathrm{L}^{-1}$, Fairchild et al., 1997). Spawn et al. (1997) observed a significant effect of alachlor on Scenedesmus spp. for concentrations up to $30 \mu \mathrm{gL}^{-1}$ and Nitzschia spp. was significantly affected at $10 \mu \mathrm{g} \mathrm{L}^{-1}$. In the present study, only the 1.6 weeks-old biofilm observed a significant loss on AFDM induced by alachlor exposure, associated certainly to its algal composition.

The present study compares the sensitivity of diatoms in biofilms of different ages and structural states to alachlor exposure. Based on assessment of species composition, no effect of alachlor was observed on the diatom communities. In the literature, the relationship between the composition of diatoms and the presence of pesticide is not clear (Morin et al., 2009). Some species are considered to be tolerant in some cases and sensitive in other cases (Guasch et al., 1998; Dorigo et al., 2004; Morin et al., 2009).

Ecological guilds (high, low and motile profiles), previously described by Passy (2007), are defined as a group of species which live in the same environment but are differently adapted to biotic factors (Passy, 2007; Berthon et al., 2011).

Dominant diatom species observed in the present study, Nitzschia palea (Kützing) W. Smith (NPAL) and Nitzschia amphibia Grunow f. amphibia (NAMP), are well known to be hypereutraphentic species and are motile guild diatoms (fast-moving mobile diatoms) (Rimet and Bouchez, 2011; Roubeix et al., 2011b). For example, NPAL which has been indicated as resistant to atrazine exposure (Guasch et al., 1998; Downing et al., 2004), exhibited an increased abundance with pesticide contamination (diuron, azoxystrobin and tebuconazole, Rimet and Bouchez, 2011), and appeared indifferent to diuron exposure in another study (Roubeix et al., 2011b). Various studies have shown that the species of diatoms selected in a pesticide contaminated environment were motile guild species (Guasch et al., 1998; Dorigo et al., 2004; Morin et al., 2009).

\subsection{Influence of temporal evolution of phototropic biofilm on the response to alachlor exposure}

Intact biofilms from the experiment " 4.4 weeks" were mainly affected by the incubation period, illustrated by a high loss of
AFDM in both control and alachlor treatments (Co and A10), this may suggest that the biofilms matured and underwent sloughing (Biggs, 1996). This is in accordance with the observations on growth of biofilm and the subsequent senescence observed for growth in the RAB (Paule et al., 2011). This senescence could mask the effect induced by alachlor in " 4.4 week biofilms" in our study. During phototrophic biofilm growth in RAB (undisturbed conditions), autogenic factors are predominant favouring autogenic detachment rarely observed in natural environments (Biggs, 1996).

In the microcosm experiments, the bacterial communities were mainly influenced by the biofilm maturation processes rather than alachlor exposure during the experiment "1.6 weeks" although no changing of bacterial communities was observed in the microcosm experiments during the experiment " 4.4 weeks". These observations are in accordance with the results recorded for the growth inside the RAB (Paule et al., 2011). Indeed, during the culture, the bacterial community structure changed according to colonization time, followed by a stable phase after 4.4 weeks. In the present study, changes due to alachlor exposure may have been masked by the temporal evolution of biofilms. Therefore if river biofilms are to be effective bio-indicator of water quality (Montuelle et al., 2011), understanding this temporal dynamic will be important.

\subsection{The influence of phototrophic biofilm biodiversity on the response to alachlor exposition}

In the present study, the low-algal diversity did not increase sensitivity to alachlor, as shown by continued growth suggested by increasing AFDM values. The observed temporal changes of bacterial community structure and utilization of different carbon sources during the incubation period for biofilm collected at 1.6 weeks also indicated little impact of alachlor. Despite the species poor algal communities resulting from suspension inoculated into the microcosms and herbicide exposure, the colonization and growth of biofilms on slides occurred. These observations suggest the importance of the relationship between the stability of ecosystem and the biodiversity, which is a major question in ecology (Mac Cann, 2000). The hypothesis "stability-biodiversity" suggests that higher biodiversity is associated with higher resistance to stress. For instance, Zhang and Zhang (2006) recorded high resistance of highly diversified algal communities exposed to temperature variations. Our results are consistent with the observations of Villeneuve et al. (2011b). These authors observed that lower diversity biofilm communities from homogenous mesocosms presented no particular sensitivity to diuron. Pesce et al. (2006) demonstrated that the effect of diuron on the phototrophic communities of the biofilms depended more on the initial specific taxonomic composition than on the number of species present. Although a high taxonomic biodiversity did not correspond to high functional diversity (Hughes et al., 2007), the response of communities to stress could be mainly influenced by the presence of key species, which may change with community development or age.

\section{Conclusion}

The present work indicates that the effect of exposure to a nominal initial alachlor concentration of $10 \mu \mathrm{g} \mathrm{L}^{-1}$ (mean TWAC of $5.52 \pm 0.74 \mu \mathrm{g} \mathrm{L}^{-1}$ ) is mainly limited to reduction of phototrophic biofilm biomass associated with the inhibition of growth. There were few apparent changes detected in the ecological succession trajectories or composition of microbial communities. This effect was consistent with the mode of action of alachlor although the outcome appeared to be influenced by species composition and temporal ecological succession of biofilm communities. When biofilm structured microbial communities were exposed 
to alachlor, there was no evidence on the role of the biofilm as a barrier to alachlor. In addition, alachlor did not disturb the communities during the first stage of slide colonization, although highly conditioned by the allogenic factors at this stage of development (Lyautey et al., 2005b). Phototrophic biofilms were most strongly influenced by the temporal dynamic of microbial community development and senescence which may mask the potential effect of alachlor. Thus, in ecotoxicological experiments, it is essential to consider the age of biofilms in the assessment of potential effects. Our results showed the difficulty to distinguish the impact of pesticide from that of other perturbations, such as incubation and operating conditions. Moreover, the intact three-dimensional structure of the biofilm did not appear to confer protection from the effects of alachlor. A multitude of effects induced by the pesticides are reported in the literature and greater standardization will require to use these communities as indicators. Studying phototrophic biofilms as dynamic aggregates allowed us to undertake an ecotoxicological approach integrating the concepts of ecological succession in microbial communities and the physical three-dimensional structure of the biofilm.

\section{Acknowledgements}

This work was funded by the French National Programme EC2CO - Environmental Microbiology and by the Midi-Pyrénées Council Programme of the Pyrenean working community. We thank J.-L. Druilhe for the electrical device for continuous physico-chemical measurement in RAB, S. Karama for assistance with the T-RFLP method and S. Mastrorillo for field assistance. We also thank D. Dalger and T. Louis for bioreactor handling assistance.

\section{Appendix A. Supplementary data}

Supplementary data associated with this article can be found, in the online version, at http://dx.doi.org/10.1016/ j.aquatox.2013.09.024.

\section{References}

Abrantes, N., Pereira, R., Gonçalves, F., 2010. Occurrence of pesticides in water, sediments, and fish tissues in a lake surrounded by agricultural lands: concerning risks to humans and ecological receptors. Water Air Soil Pollut. 212, 77-88

Admiraal, W., Blanck, H., Buckert-De Jong, M., Guasch, H., Ivorra, N., Lehmann, V., Nystrom, B.A.H., Paulsson, M., Sabater, S., 1999. Short-term toxicity of zinc to microbenthic algae and bacteria in a metal polluted stream. Water Res. 33 (9), 1989-1996.

Battin, T.J., Kaplan, L.A., Newbold, J.D., Hansen, C.M.E., 2003. Contributions of microbial biofilms to ecosystem processes in stream mesocosms. Nature 426 , 439-442.

Berthon, V., Bouchez, A., Rimet, F., 2011. Using diatom life-forms and ecological guilds to assess organic pollution and trophic level in rivers: a case study of rivers in south-eastern France. Hydrobiologia 673, 259-271.

Biggs, B.J.F., 1996. Patterns in benthic algae of stream. In: Stevenson, R.J., Bothwell M.L., Lowe, R.L. (Eds.), Algal Ecology. Freshwater Benthic Ecosystem. Academic Press, San Diego, pp. 31-56.

Böger, P., Matthes, B., SchmalfuB, J., 2000. Towards the primary target of chloroacetamides - new findings pave the way. Pest Manag. Sci. 56, 497-508.

Bonnet, J.L., Bonnemoy, F., Dusser, M., Bohatier, J., 2007. Assessment of the potential toxicity of herbicides and their degradation products to nontarget cells using two microorganisms, the Bacteria Vibrio fishcheri and the Ciliate Tetrahymena pyriformis. Environ. Toxicol. 22, 78-91.

Carder, J.P., Hoagland, K.D., 1998. Combined effects of alachlor and atrazine on benthic algal communities in artificial streams. Environ. Toxicol. Chem. 17 1415-1420.

Chesters, G., Simsiman, G.V., Levy, J., Alhajjar, B.J., Fathulla, R.N., Harkin, J.M., 1989. Environmental fate of alachlor and metolachlor. Rev. Environ. Contam. Toxicol. $110,1-74$

Choi, K.H., Dodds, F.C., 1999. Comparison of two kinds of Biolog microplates (GN and ECO) in their ability to distinguish among aquatic microbial communities. J. Microbiol. Methods 36, 203-213.

Clarke, K.R., 1993. Non parametric multivariate analyses of changes in community structure. Aust. J. Ecol. 18, 117-143.
Debenest, T., Pinelli, E., Coste, M., Silvestre, J., Mazzella, N., Madigou, C., Delmas, F., 2009. Sensitivity of freshwater periphytic diatoms to agricultural herbicides. Aquat. Toxicol. 93, 11-17.

Dorigo, U., Bourrain, X., Bérard, A., Leboulanger, C., 2004. Seasonal changes in the sensitivity of river microalgae to atrazine and isoproturon along a contamination gradient. Sci. Total Environ. 318, 101-144.

Downing, H.W., Delorenzo, M.E., Fulton, M.H., Scott, G.I., Madden, C.J., Kucklick, J.R., 2004. Effects of the agricultural pesticides atrazine, chlorothalonil, and endosulfan on South Florida microbial assemblages. Ecotoxicology 13, 245-260.

Duong, T., Morin, S., Coste, M., Herlory, O., Feurtet-Mazel, A., Boudou, A., 2010. Experimental toxicity and bioaccumulation of cadmium in freshwater periphytic diatoms in relation with biofilm maturity. Sci. Total Environ. 408, 552-562.

DeLorenzo, M.E., Scott, G.I., Ross, P.E., 2001. Toxicity of pesticides to aquatic microorganisms: a review. Environ. Toxicol. Chem. 20, 84-98.

Ensz, A.P., Knapp, C.W., Graham, D.W., 2003. Influence of autochthonous dissolved organic carbon and nutrient limitation on alachlor biotransformation in aerobic aquatic systems. Environ. Sci. Technol. 37, 4157-4162.

Fairchild, J.F., Ruessler, D.S., Haverland, P.S., Carlson, A.R., 1997. Comparative sensitivity of Selenastrum capricornutum and Lemna minor to sixteen herbicides. Arch. Environ. Contam. Toxicol. 32, 353-357.

Fairchild, J.F., Ruessler, D.S., Carlson, A.R., 1998. Comparative sensitivity of five species of macrophytes and six species of algae to atrazine, metribuzin, alachlor, and metolachlor. Environ. Toxicol. Chem. 17, 1830-1834.

Foley, M.E., Sigler, V., Gruden, C.L., 2008. A multiphasic characterization of the impact of the herbicide acetochlor on freshwater bacterial communities. ISME J. 2, 56-66.

Graham, W.H., Graham, D.W., Denoyelles Jr., F., Smith, V.H., Larive, C.K., Thurman, E.M., 1999. Metolachlor and alachlor breakdown product formation patterns in aquatic field mesocosms. Environ. Sci. Technol. 33, 4471-4476.

Graham, D.W., Miley, M.K., Denoyelles, F., Smith, V.H., Thurman, E.M., Carter, R., 2000. Alachlor transformation patterns in aquatic field mesocosms under variable oxygen and nutrient conditions. Water Res. 34, 4054-4406.

Guasch, H., Munoz, I., Roses, N., Sabater, S., 1997. Changes in atrazine toxicity throughout succession of stream periphyton communities. J. Appl. Physiol. 9, $137-146$.

Guasch, H., Ivorra, N., Lehmann, V., Paulsson, M., Real, M., Sabater, S., 1998. Community composition and sensitivity of periphyton to atrazine in flowing waters: the role of environmental factors. J. Appl. Physiol. 10, 203-213.

Guasch, H., Admiraal, W., Sabater, S., 2003. Contrasting effects of organic and inorganic toxicants on freshwater periphyton. Aquat. Toxicol. 64, 165-175.

Guasch, H., Bonet, B., Bonnineau, C., Corcoll, N., Lopez-Doval, J.C., Munoz, I., Ricart, M., Serra, A., Clements, W., 2012. How to link field observations with causality? Field and experimental approaches linking chemical pollution with ecological alterations. In: Guasch, H., Ginebreda, A., Geiszinge, A. (Eds.), Emerging and Priority Pollutants in Rivers, The Handbook of Environmental Chemistry, vol. 19 Springer-Verlag, Berlin, Heidelberg, pp. 181-218.

Hillebrand, H., Sommer, U., 2000. Effect of continuous nutrient enrichment on microalgae colonizing hard substrates. Hydrobiologia 426, 185-192.

Hughes, R., Byrnes, J., Kimbro, D., Stachowicz, J., 2007. Reciprocal relationship and potential feedbacks between biodiversity and disturbance. Ecology Let. 10, 849-864.

Ivorra, N., Bremer, S., Guasch, H., Kraak, M.H.S., Admiraal, W., 2000. Differences in the sensitivity of benthic microalgae to $\mathrm{Zn}$ and $\mathrm{Cd}$ regarding biofilm development and exposure history. Environ. Toxicol. Chem. 19 (5), 1332-1339.

Junghans, M., Backhaus, T., Faust, M., Scholze, M., Grimme, L.H., 2003. Predictability of combined effects of eight chloroacetanilide herbicides on algal reproduction. Pest Manag. Sci. 59, 1101-1110.

Jurgensen, T.A., Hoagland, K.D., 1990. Effects of short-term pulses of atrazine on attached algal communities in a small stream. Arch. Environ. Contam. Toxicol. 19, 617-623.

Knapp, C.W., Graham, D.W., Berardesco, G., deNoyelles Jr., F., Cutak, B.J., Larive, C.K. 2003. Nutrient level, microbial activity, and alachlor transformation in aerobic aquatic systems. Water Res. 37, 4761-4769.

Kreuger, J., 1998. Pesticides in stream water within an agricultural catchment in southern Sweden, 1990-1996. Sci. Total Environ. 216, 227-251.

Kröpfl, K., Vladár, P., Szabó, K., Acs, E., Borsodi, A.K., Szikora, S., Caroli, S., Záray, G., 2006. Chemical and biological characterisation of biofilms formed on different substrata in Tisza river (Hungary). Environ. Pollut. 144, 626-631.

Laabs, V., Wehrhan, A., Pinto, A., Dores, E., Amelung, W., 2007. Pesticide fate in tropical wetlands of Brazil; an aquatic microcosm study under semi-field conditions. Chemosphere 67, 975-989.

Lane, C.M., Taffs, K.H., Corfield, J.L., 2003. A comparison of diatom community structure on natural and artificial substrata. Hydrobiologia 493 (1-3), 65-79.

Lawrence, J.R., Kopf, G., Headley, J.V., Neu, T.R., 2001. Sorption and metabolism of selected herbicides in river biofilm communities. Can. J. Microbiol. 47, 634-641.

Leflaive, J., Céréghino, R., Danger, M., Lacroix, G., Ten-Hage, L., 2005. Assessment of self -organizing maps to analyse sole - carbon source utilization profiles. J. Microbiol. Methods 62, 89-102.

Liu, H.J., Xiong, M., 2009. Comparative toxicity of racemic metolachlor and Smetolachlor to Chlorella pyrenoidosa. Aquat. Toxicol. 93, 100-106.

Lyautey, E., Lacoste, B., Ten-Hage, L., Rols, J.L., Garabetian, F., 2005a. Analysis of bacterial diversity in river biofilms using 16S rDNA PCR-DGGE: methodological settings and fingerprints interpretation. Water Res. 39, 380-388.

Lyautey, E., Jackson, C.R., Cayrou, J., Rols, J.L., Garabetian, F., 2005b. Bacterial community succession in natural river biofilm assemblages. Microb. Ecol. 50, 589-601.

Mac Cann, K., 2000. The diversity-stability debate. Nature 405, 228-233. 
Mohr, S., Feibicke, M., Berghahn, R., Schmiediche, R., Schmidt, R., 2008. Response of plankton communities in freshwater pond and stream mesocosms to the herbicide metazachlor. Environ. Pollut. 152, 530-542.

Montuelle, B., Dorigo, U., Berard, A., Volat, B., Bouchez, A., Tlili, A., Gouy, V., Pesce, S., 2011. The periphyton as a multimetric bioindicator for assessing the impact of land use on rivers: an overview of the ArdiSres-Morcille experimental watershed (France). Hydrobiologia 657, 123-141.

Morin, S., Bottin, M., Mazzella, N., Macary, F., Delmas, F., Winterton, P., Coste, M., 2009. Linking diatom community structure to pesticide input as evaluated through a spatial contamination potential (Phytopixal): a case study in the Neste river system (South-West France). Aquat. Toxicol. 94, 28-39.

Murdock, J.N., Dodds, W.K., 2007. Linking benthic algal biomass to stream substratum topography. J. Phycol. 43, 449-460.

Noack, U., Geffke, T., Balasubramanian, R., Papenbrock, J., Braune, M., Scheerbaum, D., 2004. Effects of the herbicide metazachlor on phytoplankton and periphyton communities in outdoor mesocosms. Acta Hydrochim. Hydrobiol. 31, 482-490.

Osborne, C.A., Rees, G.N., Bernstein, Y., Janssen, P.H., 2006. New threshold and confidence estimates for terminal restriction fragment length polymorphism analysis of complex bacterial communities. Appl. Environ. Microbiol. 72, 1270-1278.

Pappas, J.L., Stoermer, E.F., 1996. Quantitative method for determining a representative algal sample count. J. Phycol. 32, 693-696.

Passy, S.I., 2007. Diatom ecological guilds display distinct and predictable behavior along nutrient and disturbance gradients in running waters. Aquat. Bot. 86, $171-178$.

Paule, A., Lauga, B., Ten-Hage, L., Morchain, J., Duran, R., Paul, E., Rols, J.L., 2011. A photosynthetic rotating annular bioreactor (Taylor-Couette type flow) for phototrophic biofilms cultures. Water Res. 45, 6107-6118.

Paule, A., Lyautey, E., Garabetian, F., Rols, J.L., 2009. Autogenic versus environmental control during development of river biofilm. Ann. Limnol-Int. J. Lim. 45, 1-10.

Payraudeau, S., Junker, P., Imfeld, G., Gregoire, C., 2009. Characterizing hydrological connectivity to identify critical source areas for pesticides losses. In: 18th World IMACS/MODSIM Congress: Interfacing Modelling and Simulation with Mathematical and Computational Sciences, Cairns, Australia, pp. 1879-1885.

Pesce, S., Fajon, C., Bardot, C., Bonnemoy, F., Portelli, C., Bohatier, J., 2006. Effects of the phenylurea herbicide diuron on natural riverine microbial communities in an experimental study. Aquat. Toxicol. 78, 303-314.

Pesce, S., Bouchez, A., Montuelle, B., 2011. Effects of organic herbicides on phototrophic microbial communities in freshwater ecosystems. Rev. Environ. Contam. Toxicol. 214, 87-124.

Pratt, J.R., Barreiro, R., 1998. Influence of trophic status on the toxic effects of herbicide: a microcosm study. Arch. Environ. Contam. Toxicol. 35, 404-411.

Relyea, R.A., 2009. A cocktail of contaminants: how mixtures of pesticides at low concentrations affect aquatic communities. Oecologia 159, 363-376.

Rimet, F., Bouchez, A., 2011. Use of diatom life-forms and ecological guilds to assess pesticide contamination in rivers: lotic mesocosm approaches. Ecol. Indic. 11, 489-499.

Roubeix, V., Mazzella, N., Mechin, B., Coste, M., Delmas, F., 2011a. Impact of the herbicide metolachlor on river periphytic diatoms: experimental comparison of descriptors at different biological organization levels. Ann. Limnol-Int. J. Lim. 47, 239-249.

Roubeix, V., Mazzella, N., Schouler, L., Fauvelle, V., Morin, S., Coste, M., Delmas, F., Margoum, C., 2011b. Variations of periphytic diatom sensitivity to the herbicide diuron and relation to species distribution in a contamination gradient: implications for biomonitoring. J. Environ. Monit. 13, 1768-1774.

Roubeix, V., Fauvelle, V., Tison-Rosebery, J., Mazzella, N., Coste, M., Delmas, F., 2012. Assessing the impact of chloroacetanilide herbicides and their metabolites on periphyton in the Leyre River (SW France) via short term growth inhibition tests on autochthonous diatoms. J. Environ. Monit. 14, 1655-1663.

Singh, S., Datta, P., 2005. Growth and survival potentials of immobilized diazotrophic cyanobacterial isolates exposed to common ricefield herbicides. World J. Microbiol. Biotechnol. 21, 441-446.

Smith, C.J., Danilowicz, B.S., Clear, A.K., Costello, F.J., Wilson, B., Meijer, W.G., 2005. TAlign, a web-based tool for comparison of multiple terminal restriction fragment length polymorphism profiles. FEMS Microbiol. Ecol. 54, 375-380.

Spawn, R., Hoagland, K.D., Siegfried, B., 1997. Effects of alachlor on an algal community from a midwestern agricultural stream. Environ. Toxicol. Chem. 16, 785-793.

Taghavi, L., Probst, J.L., Merlina, G., Marchand, A.L., Durbe, G., Probst, A., 2010. Flood event impact on pesticide transfer in a small agricultural catchment (Montousse at Aurade, south west France). Int. J. Environ. Anal. Chem. 90, 3-6.

Tlili, A., Dorigo, U., Montuelle, B., Margoum, C., Carluer, N., Gouy, V., Bouchez, A Berard, A., 2008. Responses of chronically contaminated biofilms to short pulses of diuron - an experimental study simulating flooding events in a small river. Aquat. Toxicol. 87, 252-263.

Tlili, A., Berard, A., Roulier, J.L., Volat, B., Montuelle, B., 2010. $\mathrm{PO}_{4}{ }^{3-}$ dependence of the tolerance of autotrophic and heterotrophic biofilm communities to copper and diuron. Aquat. Toxicol. 98, 165-177.

Tlili, A., Montuelle, B., Berard, A., Bouchez, A., 2011. Impact of chronic and acute pesticide exposures on periphyton communities. Sci. Total Environ. 409, 2102-2113.

Utermöhl, H. 1958. Zur vervollkommnung der quantitativen phytoplankton methodik. Mitteilungen Internationale Vereinigung für Theoretische und Angewandte Limnologie 9, 1-38.

Valloton, N., Moser, D., Eggen, R.I.L., Junghans, M., Chèvre, N., 2008. S-metolachlor pulse exposure on the algae Scenedesmus vacuolatus: effects during exposure and the subsequent recovery. Chemosphere 73, 395-400.

Vercraene-Eairmal, M., Lauga, B., Saint Laurent, S., Mazella, N., Boutry, S., Simon, M., Solange, K., Delmas, F., Duran, R., 2010. Diuron biotransformation and its effects on biofilm bacterial community structure. Chemosphere 81, 837-843.

Villeneuve, A., Bouchez, A., Montuelle, B., 2011a. In situ interactions between the effects of season, current velocity and pollution on a river biofilm. Freshw. Biol. $56,2245-2259$

Villeneuve, A., Montuelle, B., Bouchez, A., 2011b. Effects of flow regime and pesticides on periphytic communities: evolution and role of biodiversity. Aquat. Toxicol. 102, 123-133.

Villeneuve, A., Larroudé, S., Humbert, J.F., 2011c. Herbicide contamination of freshwater ecosystem: impact on microbial communities. In: Stoytcheva, M. (Ed.), Pesticides - Formulations, Effects, Fate. InTech, Rijeka, Croatia, pp. 285-312.

Wicke, D., Bockelmann, U., Reemtsma, T., 2008. Environmental influences on the partitioning and diffusion of hydrophobic organic contaminants in microbial Biofilms. Environ. Sci. Technol. 42, 1990-1996.

Zhang, Q.G., Zhang, D.Y., 2006. Species richness destabilizes ecosystem functioning in experimental aquatic microcosms. Oikos 112, 218-226.

Zippel, B., Neu, T.R., 2005. Growth and structure of phototrophic biofilms under controlled light conditions. Water Sci. Technol. 52, 203-209. 